\title{
SITUATION AND PROSPECTS OF CUSTOMS POLICY AND AGENCY IN BULGARIA
}

\author{
I. Nencheva-Ivanova* \\ Trakia University, Stara Zagora, Bulgaria
}

\begin{abstract}
The intense and multilateral development of international trade requires that optimal strategies are introduced into customs practice to simplify and speed up the customs process. The alignment of international customs legislation and the consolidation of unified technologies to customs control is a global trend validating in favor of current customs administrations and contemporary international trade patterns.

The development of this process requires the use of various forms of mediation between the trader and the customs authority. They appear to be an objective need of both sides in these relationships. The dynamics of the external trade flows presupposes that customs clearance takes place within regulated deadlines and at different geographic points, which of course necessitates a knowledge of at least two customs laws because the contemporary aspects of international economic relations have long gone beyond bilateral relations.
\end{abstract}

Keywords: customs activity, customs agents, customs legislation, international trade

Foreign trade regime of each country is an important instrument to adjust its foreign economic activity. Main principles are stimulating export, increasing competitiveness of domestic goods, stabilization of internal market. All this is carried out in the context of Bulgarian membership in world trade organization, in fulfillment of its international commitments.

Customs policy is a set of activities and mechanisms designed to regulate foreign trade and to protect the national economy from competition coming from cheaper goods and services from abroad.

The aim of the study to investigate state of customs policy in Bulgaria and perspectives for its development.

In order to achieve the aim are set the following tasks:

1.To analyze state of Bulgarian customs and foreign trade policy.

\footnotetext{
*Correspondence to: Assos. prof. Iskra Nencheva - Ivanova, PhD; Trakia University, Faculty of Economics, Stara Zagora, Bulgaria; e-mail: iskranencheva@abv.bg;www.uni-sz.bg
}

2.To be presented and analyzed Bulgarian opportunities for development of foreign trade and strategy.

3. To derive conclusions and recommendations on the researched topic.

Methods, applied in order to achieve the aim and accomplish the tasks are analysis and synthesis, systematic and structured approach and others.

Customs policy is a set of activities, which country applies in order to regulate foreign trade strategy.

Elements of customs policy are:

- existing duties, taxes and charges;

- organization developed to carry out customs policy;

- management of customs policy, which includes: planning, analysis, accountability and control.

Planning is carried out on the basis of the accepted foreign trade strategy, and it is accomplished by the Ministry of trade and tourism and Ministry of finance under the influence of internal and external factors. 
External factors are signed agreements by Bulgaria for decreasing and removing customs duties with international organizations: world trade organization, internationally monetary fund, joining customs union of Europe; attitude of foreign investors and the rating of the country, etc.

Among internal factors, having influence, are: decreasing volume of import; restructuring of our economy; formation of new export and import structure, complying with the requirements of the European one and world markets, change stakes of customs duties for separate goods and whole groups.

The issue with tariffs and customs policy has an important place in the economic relations between the countries. It is particularly relevant nowadays, when processes of globalization of world economy make progress with high speed.

Customs policy has strategic place in the foreign economic policy of states and supranational associations and serves as one of the key regulators of their relations with third countries.

Processes of intense development and deepen international relations of Bulgaria, accelerated growth of foreign trade, multilateral expand of passenger messages, diverse transportforwarding functions etc., on one hand and limited customs control units on the other, formulate as an important task facing customs administration the necessity of continuous research and analyses of the technology of customs process in border and internal operational zones and opportunities for introduction of rational conceptions for optimization of control power.

After Bulgaria joined the EU Bulgarian administration has taken the responsibility for protection and control of the Bulgarian part of the external borders of EU.

Customs union is a notion from economy, which expresses level of economical integration. Customs union is more than just zone for free trade it is also a common customs policy. This means, member states form single customs zone to third countries and remove all internal tariff and non-tariff trade restrictions. As a result of this countries from the union apply single customs tariff (on import and export of goods from and to third countries), valid for the whole customs unit.
NENCHEVA-IVANOVA I.

Reasons for establishing customs union are economical and political, and the effects of its establishment - positive or negative.

Among the most important positive effects are: achieving greater efficiency in production (economies of scale in production) and creating new commercial flows. Certain effects are: divert part of international trade affected by the creation of the union, as well as redistribution of economical goods between consumers, producers and state. Divert of trade flows could be described as a consequence of indirect discrimination of external to the customs union countries, because every economic integration is automatically disintegration to the non member states.

Example for a customs union from nowadays is the South African customs union. European Union, representing much higher level of regional integration (economical as well as political), also includes and the rate customs union.

\section{ESSENCE OF CUSTOMS POLICY}

Customs union is a foundation of the European Union and main element in the functioning of a single market. Customs market could function correctly if only are correctly applied common rules for external borders.

Existence of common European standards is obligatory condition in order EU to function as a single organism.

On $1^{\text {st }}$ of July 1968 Belgium, Netherlands, Luxembourg, France, Germany and Italy establish European Customs Union. This is the foundation of a single market of the EU. Fundamental principle of this act is the free movement of goods, people, services and capital. In this way EU becomes one of the biggest markets in the world. Establishment, development and management of the common market, where goods move freely, is possible only within the borders of the customs union, in which are established common standards on its external borders. Customs union creates conditions for common policy for trade and development of EU, for functioning of the agricultural market and for the effective implementation of the economical and monetary policies.

Common rules of trade within the borders of single market are a prerequisite for its existence and development. Combination of rules and standards form common customs 
policy of the Community and is an important prerequisite for member states customs to work in synchrony. Important factor for the success of the customs union is the removal of customs duty in mutual trade and applying of common customs tariffs while trading with non member states countries. Synchron of processing of goods and subjects, passing whichever of the Community's borders, is ensured by the common customs legislation, single veterinary and phyto-sanitary legislation, as well as legislation, accepted within the borders of the common trade policy.

Since joining the EU on 01.01.2007 Bulgaria has become member of the customs union. This fact has given not only new opportunities for development of our economy as far as implementation of new technologies is concerned, creating and distributing goods and services, but the single market also has imposed different rules. Bulgaria had to meet the new requirements and increased competition, which already existed in the EU. Incorporation of Bulgarian economy to the single market meant for us to accept the established common European frame. In order to go freely on the EU market, Bulgarian goods had to meet commonly accepted European standards as far as different products are concerned. These requirements and standards are written in legal documents of the union and guarantee health and safety of people and animals, quality of goods, environmental protection and others.

European standards in production are different for every type of product. Producers should meet requirements for safety and quality, which are described in details in the legal documents, and are specific for each type of product. These requirements are obligatory. Every producer should meet them, in order to have access to the European market and to compete successfully with other entrepreneurs. Bulgaria is a full member of EU since 01.01.2007. In order this to become a fact Bulgaria had to meet certain economical and political criteria, as well as to make changes in legislation. The act of joining of our country to the EU did not end the process of integration. It is a dynamic and open process, where policies of European countries in all spheres of economic and social life become similar. Bulgarian membership in EU imposed serious changes in the economy. Establishing effective cooperation between member states within the EU supposes changes in the internal legislation of each of them in order common requirements to be met. In Bulgaria are developed programs for achieving common goals of the union fight against organized crime and corruption. Border and customs control are improved. A lot of effort is put into work on the expansion and strengthening of law enforcement and judicial authorities, establishing a unified information system, staff training.

How European standards support European customs union?

What Bulgarian customs services should change in the process of integration of the country in the EU?

Joining of Bulgaria to the EU and to the single internal market set requirement to the Bulgarian customs administration to exercise protection and control of part of the external border of EU. Preparation for bringing together of customs legislation and practical application of regimes and procedures, similar to the ones applied by the customs services of the EU, as well as development of certain infrastructures allowed our country to fulfill its functions of the trade regime of the Community and to guarantee protection and control of the "external borders" of the EU.

Regulations and definition of custom duty includes sets of laws, rules, instructions and decrees of the Council of Ministers, international conventions, agreements and others. Good knowledge of regulations is a basic prerequisite for successful finalization of every customs procedure. Work on customs includes different in content and character procedures. These procedures affect both work of customs authorities, as well as obligations and functions of traders and physical person, importers or exporters of goods and services. Procedures are carried out in preliminary established order and include obligatory actions like documentation, inspection, impose customs-duty on, provision and collection of customs duties, which also requires good knowledge of customs - legal matter.

After joining to the common trade policy of the EU Bulgaria should implement integrated customs tariff TARIC and adequate computer system, to harmonize its legislation in the field with goods with cultural character, the regimes of non-proliferation of weapons of mass destruction and goods with possible dual-use.

Customs administration has been given certain powers for the implementation of Community 
policies. In this way stay time at the borders will be reduced, intellectual property rights will be protected, the fight against economical and organized crime will be more effective.

Bulgaria should also apply suitable education systems, which should contribute to achievement of the main goal - professional and motivated customs administration and stable work conditions for customs staff.

Important achievement was equalization of the customs declaration and application corresponding in form, content and purpose of the Single Administrative Document. Equalized are procedures for the implementation of the customs procedures, and customs concessions with those of the European Union.

Another important element of the reform and modernization in customs is the developed in 1999 Business strategy of the customs administration, which includes its mission and goals and a plan for particular actions till 2001. In the next years it was changed in order to follow the stages of preparation for the joining of EU.

Amendments act to the customs act was adopted, in order to point out changes in Bulgarian legislation and to achieve greater harmonization with customs codex of EU. In relation to the conducted reform, General department of customs converted to customs agency, organized in four levels of management. After Bulgaria joined European Customs Union, our customs authorities accepted European standards for work and service.

These are: usage of electronic informational systems for implementation of the accepted by the EU long term strategic plan for e-customs. It includes legislative changes and simplification, operational compatibility and computerization of customs process. Bulgarian integrated customs informational system (BICIS) is connected with the relevant systems of the EU. This increases the ability of our customs to share information with other member states of the EU. This information is of significant importance, for both Bulgaria and EU, having in mind our new responsibilities, as external border of the Community. The system is important also because through it Bulgaria can apply the common customs tariff of the EU and would easier join to the common European economic space.

European standards are applied mainly at the control of our borders. Customs control check imported and exported goods, in order to determine whether import or export is legal and to define quality, quantity and value of the imported and exported goods. This system could be stable only if relations within the union are stable. Effective control is necessary at every checkpoint, because goods entering any member state could freely move everywhere within the Union.

\section{ROLE OF CUSTOMS NOWADAYS.}

Main role of customs of EU is to facilitate trade, stimulate production in EU, protection of citizens of EU.

Customs authorities exercise policies of EU in almost every sphere, connected with international trade. They are in the front line in the fight against frauds, terrorism and organized crime.

Mission of customs administration is defined by the development of the society, from its increasing requirements to establish optimal economic environment determined by liberal and effective trade policy. Together with that society requires customs administration to protect its achievements by opposing effectively to the violation and crimes against fiscal interest, cultural heritage and intellectual products and to protect life and health of citizens.

Its responsibilities are:

$>$ facilitate functioning of the market,

$>$ to ensure proper applying of policies of the EU,

$>$ to ensure control over external borders,

$>$ to protect society from dangerous goods,

$>$ to apply correctly the common customs tariff, common system for preferences, anti dumping measures and others which are basic for the functioning of the common European economy.

Main function of customs administration is collection of customs duties and other government claims of its competence. Bulgarian customs administration cooperates for protection of cultural heritage and protection of rights over intellectual property. Administration collects and analyses statistical data of international trade, takes part in development and execution of international 
contracts, which refer to customs activity and carry out international customs relations.

Measures and fight against illegal traffic of protected species, which in recent years has become more serious problem and acquired dimensions that put at risk more the wild flora and fauna representatives. On global scale profit of this natural wealth detrimental activity increased. According to United Nations Organization annually they are estimated to be around 10 milliard dollars (without including traffic of timber from endangered tree species and threatened species of fish). Illegal trade with protected species is the most profitable after traffic of drugs and weapon.

\section{CONCLUSION}

Development of international integration processes and the intensification of foreign trade relations between different countries increasingly raised the role of customs control as a significant part of the whole process. Recently known just as a management function, which main task is to protect the monopoly of foreign trade, today it becomes specialized control with the multiple action.

Nowadays development of customs control goes out of the framework of a single formal action and becomes an important economic regulator of foreign trade goods flows.

A lot of studies, publications, articles, economic research have been dedicated to the problems of custom duty and customs policy.
The significant interest in this topic, not only by the specialists, but also by the society as whole, should be given to the direct reflection, which customs policy has over everyday life of each of us. To a great extent customs policy is responsible for life standard of people, employment, national production national prosperity. Therefore, customs policy and effectiveness of customs policy should not be neglected.

To what extent government actions in this direction are successful depends mostly on the political goodwill of the governing ones. Of course, external factor also have influence like strive to enhance the integration process (as it is the striving of Bulgaria toward EU), striving to improve trade conditions and to increase tax revenue. However we should not forget that, whatever are the reasons for intervention and change of customs policy, they should arise from one motive - improvement of prosperity of the nation, protection of national priorities and the security of the state.

\section{REFERENCES}

1. Avramov, Y., Customs and Tax Control, Sofia, 2002.

2. Velichkov, V., "Customs Theory. Customs Border", Trakia -M, Sofia, 2008.

3. Dimov, O., "European Customs Control", Sofia, 2011.

4. Mladenov, P., Customs Representation and Agency, Sofia, 2008.

5. Customs Chronicle Magazine. 